\title{
COMPARATIVE MULTICENTER STUDY OF TREATMENT OF MULTI-FRAGMENTED TIBIAL DIAPHYSEAL FRACTURES WITH NONREAMED INTERLOCKING NAILS AND WITH BRIDGING PLATES
}

Hélio Jorge Alvachian Fernandes, Marcos Hideyo Sakaki Jorge dos Santos Silva, Fernando Baldy dos Reis, Arnaldo Valdir Zumiotti

Fernandes HJA, Sakaki MH, Silva JS, Reis FB, Zumiotti AV. Comparative multicenter study of treatment of multi-fragmented tibial diaphyseal fractures with nonreamed interlocking nails and with bridging plates. Clinics. 2006;61(4):333-38.

OBJECTIVE: A prospective, randomized study to compare patients with closed, multi-fragmented tibial diaphyseal fractures treated using one of two fixation methods undertaken during minimally invasive surgery: nonreamed interlocking intramedullary nails or bridging plates.

MATERIALS AND METHODS: Forty-five patients were studied; 22 patients were treated with bridging plates, 23 with interlocking nails without reaming. All fractures were Type B and C (according to the AO classification).

RESULTS: Clinical and radiographic healing occurred in all cases. No cases of infection occurred. The healing time for patients who received nails was longer ( 4.32 weeks on average) than the healing time for those who received plates $(P=0.026)$. No significant differences were observed between the two methods regarding ankle mobility for patients in the two groups.

CONCLUSIONS: The healing time was shorter with the bridging plate technique, although no significant functional differences were found.

KEY WORDS: Intramedullary fixation of fractures. Tibial fractures. Bridging plates. Diaphysis. Comminuted fractures.

\section{INTRODUCTION}

Most tibial fractures occur in the long bones of adults. A review of the literature did not provide papers that were appropriate to reach a decision about the best management method. ${ }^{1}$ Usually, low-energy fractures are not treated surgically, but rather by bloodless reduction and plastered immobilization, while for fractures secondary to high-energy traumas, a trend exists towards using the surgical approach.

With the purpose of comparing surgical methods of treatment, a prospective, randomized, multicenter study on multi-fragmented tibial diaphyseal fractures was conducted

Department of Orthopedics and Traumatology, Clinics Hospital, Faculty of Medicine, University of Sao Paulo/ SP, Brazil.

Email:zumiotti@hcnet.usp.br

Received for publication on February 26, 2006.

Accepted for publication on May 10, 2006. in 2 institutions, namely the Departments of Orthopedics of the University of São Paulo and of the Federal University of São Paulo.

\section{MATERIALS AND METHODS}

The inclusion criteria for this study were patients with closed, multi-fragmented tibial diaphyseal fractures. Threshold cases of very proximal or distal fractures were excluded using the square rule ${ }^{2}$. A protocol was developed that included recording patients' general data plus the cause and location of the fracture, as well as its association with fibular fracture, its classification, the time from accident to surgery, and the follow-up period (Tables 1, 2, and 3). The surgical treatment procedures employed minimally invasive technique with nonreamed interlocking intramedullary nails or bridging plates. Patients were randomly allocated at the surgical center. 
Table 1 - Distribution of patients per group and cause of fracture

\begin{tabular}{lccc}
\hline & \multicolumn{3}{c}{ Group } \\
Cause & Nail & Plate & Total \\
\hline car accident & 5 & 4 & 9 \\
motorcycle accident & 3 & 5 & 8 \\
run-over accident & 9 & 7 & 16 \\
car accident + run-over accident & 0 & 1 & 1 \\
fall & 4 & 3 & 7 \\
direct trauma & 2 & 2 & 4 \\
Total & 23 & 22 & 45 \\
\hline
\end{tabular}

Table 2 - Distribution of patients per group and according to the AO classification

\begin{tabular}{lccc}
\hline & \multicolumn{3}{c}{ Group } \\
AO & Nail & Plate & Total \\
\hline B1 & 6 & 1 & 7 \\
B2 & 7 & 10 & 17 \\
B3 & 5 & 5 & 10 \\
C1 & 1 & 0 & 1 \\
C2 & 3 & 4 & 7 \\
C3 & 1 & 2 & 3 \\
Total & 23 & 22 & 45 \\
\hline
\end{tabular}

Table 3 - Distribution of patients by group and fracture site

\begin{tabular}{lccc}
\hline Site & Nail & $\begin{array}{c}\text { Group } \\
\text { Plate }\end{array}$ & Total \\
\hline Distal & 9 & 4 & 13 \\
Medial & 13 & 13 & 26 \\
Medial/Distal & 1 & 3 & 4 \\
Proximal & 0 & 1 & 1 \\
Proximal/Medial/Distal & 0 & 1 & 1 \\
Total & 23 & 22 & 45 \\
\hline
\end{tabular}

Forty-five patients were studied, with 22 patients receiving bridging plates and 23 receiving interlocking nails, and with the location of treatment as follows: 26 patients (13 plates, 13 nails) at the Federal University of São Paulo, and 19 patients (9 plates, 10 nails) at the Institute of Orthopedics and Traumatology, Faculty of Medicine, University of Sao Paulo, SP (Brazil). The study period was from January 2002 to June 2003. The follow-up period varied between 6 months to 1 year. This protocol was approved by the Ethics Committees of the participant institutions and signed informed consent obtained from each included patient.

The surgical technique consisted of indirect reduction for both forms of osteosynthesis without violation of the fracture focus. The blocked intramedullary nails used were AO universal steel nails introduced with no medullary channel reaming. We used a narrow plate for large fragments (4.5 mm AO).
The average values for age, time from accident to surgery, and follow-up period were, respectively, 34 years, 23 days, and 51 weeks for the group treated with intramedullary nails, and 34 years, 34 days, and 32 weeks for the group treated with bridging plates.

We used Student's $t$ test for independent samples ${ }^{3}$ to compare the numerical measurements of patients for these preliminary conditions

In the group treated with intramedullary nails, 4 patients were women and 19 were men, while in the group treated with a bridging plate, 3 were women and 19 were men.

Eleven individuals were smokers and 12 were nonsmokers in the group treated with nails, while 13 were smokers and 7 were nonsmokers in the group treated with plates.

Tibial fracture was accompanied by fibular fracture in 18 patients of the group treated with nails and in 10 patients of the group treated with plates; 5 and 12 patients, respectively, presented with intact fibulae.

We used the chi-square test or Fisher's exact test (as required for each case $^{2}$ ) to compare groups according to categorical variables.

\section{RESULTS}

The results obtained regarding healing time as well as complications such as angulation, shortening, infection, healing delay, pseudoarthrosis, and ankle mobility are presented in Tables 4 and 5 for patients who received bridging plates and blocked intramedullary nails, respectively.

The results of the statistical analysis of cases are shown in Table 6.

The groups were homogeneous concerning age, and on average, they had the same time from accident to surgery, while patients who received nails had significantly longer follow-up periods.

The groups were not different regarding sex or smoking. More isolated fractures were found among the individuals who received nails as compared with those who received plates.

The healing time for patients who received nails was significantly longer, by an average of 4.30 weeks, than the healing time for those who received bridging plates $(P=0.019$, Student's $t$ test applied for independent samples) (Table 7).

There were no significant differences when comparing the two groups for the following parameters: infection, healing delay $(P=0.109$, Fisher's test), pseudoarthrosis, angulation $>10$ degrees, shortening $>1 \mathrm{~cm}$, and ankle mobility $(P=0.243$, Fisher's test).

\section{DISCUSSION}

According to the AO classification, multi-fragmented 
Table 4 - Individual results for patients undergoing a surgical treatment with bridging plates: ordinal number, healing time, infection, healing delay, pseudoarthrosis, angulation, shortening, and ankle mobility

\begin{tabular}{|c|c|c|c|c|c|c|c|}
\hline $\begin{array}{l}\text { Ordinal } \\
\text { number }\end{array}$ & $\begin{array}{l}\text { Healing time } \\
\text { (weeks) }\end{array}$ & Infection & $\begin{array}{l}\text { Healing } \\
\text { delay }\end{array}$ & $\begin{array}{l}\text { Pseudo- } \\
\text { arthrosis }\end{array}$ & $\begin{array}{l}\text { Angulation } \\
>10^{\circ}\end{array}$ & $\begin{array}{l}\text { Shortening } \\
>1 \mathrm{~cm}\end{array}$ & $\begin{array}{l}\text { Ankle } \\
\text { mobility }\end{array}$ \\
\hline 1 & 20 & no & no & no & no & no & incomplete \\
\hline 2 & 16 & no & no & no & no & no & complete \\
\hline 3 & 15 & no & no & no & no & no & complete \\
\hline 4 & 22 & no & no & no & no & no & incomplete \\
\hline 5 & 13 & no & no & no & no & no & complete \\
\hline 6 & 22 & no & no & no & no & no & complete \\
\hline 7 & 16 & no & no & no & no & no & incomplete \\
\hline 8 & 18 & no & no & no & no & no & complete \\
\hline 9 & 13 & no & no & no & no & no & complete \\
\hline 10 & 13 & no & no & no & no & no & complete \\
\hline 11 & 13 & no & no & no & no & no & complete \\
\hline 12 & 13 & no & no & no & no & no & complete \\
\hline 13 & 14 & no & no & no & no & no & complete \\
\hline 14 & 13 & no & no & no & no & no & complete \\
\hline 15 & 16 & no & no & no & no & no & incomplete \\
\hline 16 & 14 & no & no & no & no & no & complete \\
\hline 17 & 14 & no & no & no & no & no & complete \\
\hline 18 & 15 & no & no & no & no & no & complete \\
\hline 19 & 13 & no & no & no & no & no & complete \\
\hline 20 & 18 & no & no & no & no & no & incomplete \\
\hline 21 & 20 & no & no & no & no & no & complete \\
\hline 22 & 21 & no & no & no & no & no & complete \\
\hline
\end{tabular}

Sources: Sao Paulo Hospital (EPM/UNIFESP) and Institute of orthopedics and Traumatology (USP)

Table 5 - Individual results for patients undergoing surgical treatment with intramedullary nails: ordinal number, healing time, infection, healing delay, pseudoarthrosis, angulation, shortening, and ankle mobility

\begin{tabular}{|c|c|c|c|c|c|c|c|}
\hline Ordinal number & $\begin{array}{l}\text { Healing time } \\
\text { (weeks) }\end{array}$ & Infection & $\begin{array}{l}\text { Healing } \\
\text { delay }\end{array}$ & $\begin{array}{l}\text { Pseudo- } \\
\text { arthrosis }\end{array}$ & $\begin{array}{l}\text { Angulation } \\
>10^{\circ}\end{array}$ & $\begin{array}{l}\text { Shortening } \\
>1 \mathrm{~cm}\end{array}$ & $\begin{array}{l}\text { Ankle } \\
\text { mobility }\end{array}$ \\
\hline 1 & 40 & no & yes & no & no & no & complete \\
\hline 2 & 20 & no & no & no & no & no & complete \\
\hline 3 & 36 & no & yes & no & no & no & complete \\
\hline 4 & 14 & no & no & no & no & no & complete \\
\hline 5 & 14 & no & no & no & no & no & complete \\
\hline 6 & 16 & no & no & no & no & no & complete \\
\hline 7 & 26 & no & yes & no & no & no & incomplete \\
\hline 8 & 32 & no & yes & no & no & no & complete \\
\hline 9 & 22 & no & no & no & no & no & complete \\
\hline 10 & 16 & no & no & no & no & no & complete \\
\hline 11 & 16 & no & no & no & no & no & incomplete \\
\hline 12 & 14 & no & no & no & no & no & complete \\
\hline 13 & 18 & no & no & no & no & no & complete \\
\hline 14 & 18 & no & no & no & no & no & complete \\
\hline 15 & 20 & no & no & no & no & no & complete \\
\hline 16 & 20 & no & no & no & no & no & complete \\
\hline 17 & 16 & no & no & no & no & no & complete \\
\hline 18 & 13 & no & no & no & no & no & complete \\
\hline 19 & 14 & no & no & no & no & no & complete \\
\hline 20 & 15 & no & no & no & no & no & complete \\
\hline 21 & 15 & no & no & no & no & no & complete \\
\hline 22 & 32 & no & no & no & no & no & complete \\
\hline 23 & 20 & no & no & no & no & no & complete \\
\hline
\end{tabular}

Sources: Sao Paulo Hospital (EPM/UNIFESP) and Institute of Orthopedics and Traumatology (USP)

tibial diaphyseal fractures are named 42 (4 for tibia; 2 for diaphysis) and subdivided into B and C. Type B fractures present contact between the proximal and distal fragments after reduction, while Type $\mathrm{C}$ fractures are more fragmented and do not show this contact. The statistical analysis showed that both groups (nails and plates) were homogeneous concerning age, time from accident to surgery, sex, and smoking; the only difference was the increased inci- 
Table 6 - Results of comparison between groups

\begin{tabular}{lll}
\hline Variable & $\mathrm{P}$ & Test used \\
\hline Age & 0.949 & Student's t test \\
Time from accident to surgery & 0.230 & Student's t test \\
Follow-up period & 0.003 & Student's t test \\
Sex & 0.999 & Fisher's exact test \\
Smoking & 0.258 & Chi-square test \\
Single fracture & 0.023 & Chi-square test \\
\hline
\end{tabular}

Table 7 - Descriptive measurements of patients' healing time per group

\begin{tabular}{lccc}
\hline & \multicolumn{2}{c}{ Group } & \\
Measurement & Nail & Plate & $\mathrm{p}^{*}$ \\
\hline Mean & 20.30 & 16.00 & 0.019 \\
Std. deviation & 7.68 & 3.19 & \\
Minimum & 13.00 & 13.00 & \\
Maximum & 40.00 & 22.00 & \\
Asymmetry & 1.41 & 0.78 & \\
Curtosis & 1.04 & -0.81 & \\
*student's t test for healing time & & &
\end{tabular}

dence of the presence of an associated fibular fracture in the nails group.

This study was designed to compare the efficacy of treatment of closed, multi-fragmented tibial diaphyseal fractures with nonreamed interlocking intramedullary nails and with bridging plates. In both types of osteosynthesis, the aim was to apply the principle of fixation with relative stability. By using this principle for the fractures, the deformation ratio is better tolerated and leads to a lower degree of implant loading. In both cases, healing is favored by the nonviolation of the fracture focus, the formation of a secondary bone callus being expected.

For multi-fragmented fractures, surgical treatment using the open reduction technique may compromise the blood supply and lead to a healing disorder. Wide surgical exposure is required to achieve anatomical reduction and fixation with the absolute stability principle; however, in multi-fragmented fractures, this strategy can lead to a severe disturbance of the blood supply. ${ }^{2,4}$ For this reason, open reduction surgery is reserved only for single-trace diaphyseal fractures, where direct or primary healing is expected. It should be emphasized that the deformation ratio in such cases is less tolerated, and small technical inaccuracies greatly increase the loading of the implant and can lead to nonhealing and, therefore, to a defective osteosynthesis.

Many authors consider blocked intramedullary nails the implant of choice in tibial diaphyseal fractures. ${ }^{5-10}$ This was the main argument and also the main difficulty in this study, since most staff at the various Orthopedics Services who were contacted were not willing to participate in this study, alleging that intramedullary nails was the standard treatment for these fractures. Thus, only 3 institutions participated in this study, although one of them did not present enough data for inclusion in the protocol.

Bridging plates are used more often in diaphyseal fractures that compromise the proximal and distal ends of the tibia $^{11-15}$; however, in this study this aspect was not considered, since patients were randomly allocated. The placement of the plate on the anterior-medial tibial face is technically easier and leads to less compromise of its vascularization. ${ }^{16}$

We compared similar groups and observed that the clinical and radiological parameters analyzed, such as articular function, deformities, infection, and pseudarthrosis, were similar in both groups (Tables 4 and 5). The healing time was the only significant difference found. On average, bone healing in patients receiving bridging plates occurred 4 weeks earlier compared with patients who received nonreamed interlocking intramedullary nails (Table 7).

We can conclude that the healing times were significantly shorter in patients undergoing surgery with the bridging plate technique, and the functional results were not different among patients of both groups.

\section{RESUMO}

Fernandes HJA, Sakaki MH, Silva JS, Reis FB, Zumiotti AV. Estudo multicêntrico comparativo do tratamento de fraturas diafisárias multifragmentárias de tíbia com hastes bloqueadas não-fresadas e placas em ponte. Clinics. 2006;61(4):333-38.

OBJETIVOS: Estudo prospectivo e randomizado comparou pacientes com fraturas diafisárias multifragmentárias fechadas de tíbia, tratados com dois métodos de fixação: hastes intramedulares bloqueadas nãofresadas e placas em ponte.

MATERIAL E MÉTODOS: Foram estudados 45 pacientes sendo utilizadas 22 placas em ponte e 23 hastes bloqueadas. Todas as fraturas foram tipos B e C (Classificação AO). 
RESULTADOS: A consolidação clínica e radiográfica ocorreu em todos os casos. Não houve caso de infecção. Verificou-se que o tempo de consolidação dos pacientes que receberam haste foi maior (em média 4,32 semanas) do que o tempo de consolidação daqueles que receberam placa ( $p$ $=0,026)$. Não foram observadas diferenças estatisticamente significantes entre os dois métodos no tocante à mobilidade do tornozelo nos pacientes dos dois grupos.

CONCLUSÕES: O tempo de consolidação foi menor com uso de placas em ponte, porém sem diferenças funcionais significantes.

UNITERMOS: Fixação intramedular de fraturas. Fraturas da tíbia. Placas Ósseas. Diáfises. Fraturas cominutivas.

\section{REFERENCES}

1. Littenberg B, Weinstein LP, McCarren M, Mead T, Swiontkowski MF, Rudicel SA, et al. Closed fractures of the tibial shaft. A meta-analysis of three methods of treatment. J Bone Joint Surg Am. 1998;80:174-83.

2. Müller ME, Allgöwer M, Schneider R, Willenegger H. Manual de osteossíntese. $3^{\text {rd }}$ ed. Sao Paulo: Manole; 1993.

3. Altman D. Practical statistics for medical research. Chapman and Hall: London; 1997.

4. Perren SM, Claes L. Biology and biomechanics in fracture management In: Rüedi TP, Murphy WM, editors. AO principles of fracture management. New York: Thieme; 2000. p 7-31.
5. Alho A, Ekeland A, Strömsoe K, Folleras G, Thöresen BO. Locked intramedullary nailing for displaced tibial shaft fractures. J Bone Joint Surg Am. 1990;72:805-9.

6. Court-Brown C, Christie J, McQueen M. Closed intramedullary tibial nailing. Its use in closed and type I open fractures. J Bone Joint Surg Br. 1990;72:605-11.

7. Court-Brown CM, Gustilo T, Shaw AD. Knee pain after intramedullary tibial nailing: its incidence, etiology, and outcome. J Orthop Trauma. 1997;11:103-15.

8. Krettek C, Schandelmaier P, Tscherne H. Nonreamed interlocking nailing of closed tibial fractures with severe soft tissue injury. Clin Orthop. 1995;315:34-47. 
9. Tornetta P 3rd, Bergman M, Watnik N, Berkowitz G, Steuer J. Treatment of grade-IIIB open tibial fractures. A prospective randomised comparison of external fixation and non-reamed locked nailing. J Bone Joint Surg Br. 1994;76:13-9.

10. Angliss R, Tran A, Edwards E, Doig SG. Unreamed nailing of tibial shaft fractures in the multiply injured patients. Injury. 1996;27:255-60.

11. Redfern D, Syed S, Davies S. Fractures of the distal tibia: minimally invasive plate osteosynthesis. Injury. 2004;35:615-20.

12. Helfet D, Suk M. Minimally invasive percutaneous plate osteosynthesis of fractures of the distal tibia. Instr Course Lect. 2004;53:471-5.
13. Oh C, Kyung H, Park IH, Kim PT, Ihn JC. Distal tibia metaphyseal fractures treated by percutaneous plate osteosynthesis. Clin Orthop. 2003;408:286-9.

14. Cole P, Zlowodzki M, Kregor P. Less Invasive Stabilization System (LISS) for fractures of the proximal tibia: indications, surgical technique and preliminary results of the UMC Clinical Trial. Injury. 2003;34:1629.

15. Stannard J, Wilson T, Volgas D, Alonso JE. Fracture stabilization of proximal tibial fractures with the proximal tibial LISS: early experience in Bimingham, Alabama (USA). Injury. 2003;34(Suppl 1):A36-42.

16. Borrelli J Jr, Prickett W, Song E, Becker D, Ricci W. Extraosseous blood supply of the tibia and the effects of different plating techniques: a human cadaveric study. J Orthop Trauma. 2002;16:691-5. 